\title{
INTEGRATED DESIGN OF INDUSTRIALIZED BUILDING SYSTEMS: THE TECHNOLOGY CENTER OF THE SARAH NETWORK - CTRS, BRAZIL'
}

\author{
Projeto Integrado de Sistema Construtivo industrializado: \\ Centro de Tecnologia da Rede Sarah - CTRS, Brasil \\ Marieli Azoia Lukiantchuki', Michele Caroline Bueno Ferrari Caixeta', \\ Márcio Minto Fabricio'
}

\begin{abstract}
The design process of a building should be a collective activity, with the participation of different specialties. In these processes, an effective coordination is necessary to foster interactivity among the design team. In Brazil, the hospital design process developed by the architect João Filgueiras Lima at the Centro de Tecnologia da Rede Sarah Kubitschek (CTRS) [Technology Center of the Sarah Kubitschek Network] is an important example of integrated design of industrialized buildings, encompassing all stages of the building process. The CTRS was an innovative experience in the construction industrialization in Brazil, and also a major center of research. The present study analyzes the integrated design process of the CTRS through a case study based on direct observations, guided visits, surveys for data collection carried out in the CTRS design collection, and interviews with the architect João Filgueiras Lima, also known as Lelé, and professionals of his team. The results show the development of all stages of the building in the CTRS, from the planning to the maintenance, which facilitates the design process and improves the building functioning.
\end{abstract}

KEYWORDS: Integrated design, Design process, Healthcare architecture, Lelé, CTRS.

RESUMO O processo de projeto um edifício deve ser uma atividade coletiva, com a participação de diferentes especialidades. Nesses processos, uma coordenação eficaz é necessária para promover a interatividade entre os membros da equipe de projeto. No Brasil, o processo de projeto de hospitais desenvolvido pelo arquiteto João Filgueiras Lima no (CTRS) é um importante exemplo de projeto integrado de edifícios industrializados, abrangendo todas as fases do processo de construção. O CTRS foi uma experiência inovadora na industrialização da construção no Brasil, e também é um importante centro de pesquisa. O presente estudo analisa o processo de concepção projeto integrado do CTRS por meio de um estudo de caso com base em observações diretas, visitas guiadas, pesquisas para coleta de dados realizada na coleção de projetos do CTRS e entrevistas com o arquiteto João Filgueiras Lima, mais conhecido como Lelé, e com os profissionais de sua equipe. Os resultados mostram o desenvolvimento de todas as etapas da construção no CTRS, desde o planejamento até a manutenção, o que facilita o processo de projeto e melhora funcionamento do edifício.

PALAVRAS-CHAVE: Projeto integrado, Processo de projeto, Arquitetura de edifícios de saúde, Lelé, CTRS

\section{INTRODUCTION}

Building design and construction have been frequently analyzed as inefficient (GALLAHER et al., 2004; OWEN, 2009; OWEN et al., 2010; VAN NEDERVEEN; BEHESHTI; RIDDER, 2010). Due to the increasing scale and the complexity of design processes, traditional approaches may no longer be appropriated (VAN AKEN, 2005). In this context, Integrated Design and Delivery Solutions (IDDS) may play an important role in the reduction of time and costs of construction, increasing value to clients (OWEN, 2009).

\footnotetext{
How to cite this article:

LUKIANTCHUKI, M. A.; CAIXETA, M. C. B. F.; FABRICIO, M. M. Integrated design of industrialized building systems: The Technology Center Of the Sarah Network - CTRS, Brazil. Gestão e Tecnologia de Projetos, São Paulo, v. 10, n. 1, p. 103-118, jan./jun. 2015

http://dx.doi.org/10.11606/gtp.v10i1.95913
}

Fonte de financiamento: Declaram não haver. Conflito de interesse: Declaram não haver Submetido em: 05 mar. 2015 Aceito em: 06 maio 2015 
In Brazil, the hospital design process developed by the architect João Filgueiras Lima at the Technology Center of The Sarah Network of Rehabilitation Hospitals (CTRS) is an important example of integrated design of industrialized buildings. It encompasses all stages of planning, designing, production, assembling and maintenance, with collaborative work involving a multidisciplinary team coordinated by João Filgueiras Lima. The CTRS was an innovative experience of technological creation in the industrialization of construction in Brazil, and a major center of research.

The CTRS was established in 1992 with the important leadership of the architect João Filgueiras Lima, being focused on the production of rehabilitation hospitals. João Filgueiras Lima left the CTRS in 2012, passing away at May of 2014.

According to Segawa (2011), besides being a factory, the CTRS is a technological research system established to expand the Hospitals of The Sarah Network throughout the national territory. The main objective of the center is to design and build hospitals, to design and produce hospital equipment, to promote the maintenance of the buildings, and to adapt the spaces of the units to the new functional demands and to the new hospital technologies. In addition, employees were trained in the center on medical and technological innovations.

Mr. Lima improved his architectural design skills in the CTRS by creating elements using his own formal repertoire, taking advantage of more functional and bright shapes through the industrialization of construction. His designs developed at the CTRS are characterized by a high level of details, which is crucial to ensure the quality of buildings.

This study aims to describe the integrated design process at the CTRS and the interaction between the infrastructure of the production at that factory and design activities, along with the several stages of the design process. The importance of the integrated design to the development of the product is also highlighted to value the relationship with clients, and to reduce time and costs, thus emphasizing the work of the designers throughout the process. The processes of production have been addressed in another article published by the authors Lukiantchuki, Caixeta and Fabricio (2011). The case study method was the one here applied, and the data were collected using multiple evidence sources, such as direct observations, open-ended interviews, focused interviews, and the analyses of documents.

\section{BUILDINGS PRODUCED AT THE CTRS}

The design processes of hospitals at the CTRS are integrated, encompassing all stages of planning, designing, production, assembling and maintenance, with the help of a multidisciplinary team since the beginning of the process. The architect João Filgueiras Lima was the coordinator of the entire system. Hospitals are entirely produced at the CTRS and then transported to places where they will be assembled. Precast systems are applied in all stages of the building, from the superstructure to the equipment of the hospital, which includes structures, walls, facilities, among other components. The production at the CTRS is characterized as a closed system, in which only one company or organization is responsible for the production of construction subsystems, determining the rules of compatibility for all components, thus mastering the technology of the product and its development process (CAMARGO, 1975; SERRANO, 1980).

The CTRS building consists of interconnected single-storey buildings, where the following workshops are located: heavy metallurgy; light metallurgy; ferrocement; woodwork; and plastics and painting. Each workshop was produced using a heavy metallic structure for hospitals, more delicate metallic elements such as gurney-beds, doors and double walls of ferrocement, and general furniture, respectively. 
Mr. Lima's office and technical and administrative sectors are located in a mezzanine overlooking all workshops for the production monitoring. These workshops are interconnected by corridors in two overlapping levels: the upper one links to the coordinator's office, while the bottom one is used for the supply and intercommunication of production sectors (LATORRACA, 1999). The integration among the building, users and production is fundamental to Mr. Lima, whose team works really hard and discusses all details together.

The Sarah Network is composed of 10 hospitals. The first was implanted in Brasília in 1975, and then others were implanted in São Luís, Salvador, Belo Horizonte, Fortaleza, Rio de Janeiro (Children's center), Brasília (Lago Norte), Macapá, Belém, and the last one in Rio de Janeiro (Hospital) in 2009.

The first hospital was built with precast concrete, using Vierendeel Beams. Until 1978, Mr. Lima constructed buildings with heavy pieces made of precast concrete, and few elements of precast ferrocement (Figure 1). Thenceforth, his designs have evolved and the hospital in Salvador is characterized as a contemporary and fully industrialized building (Figure 2).

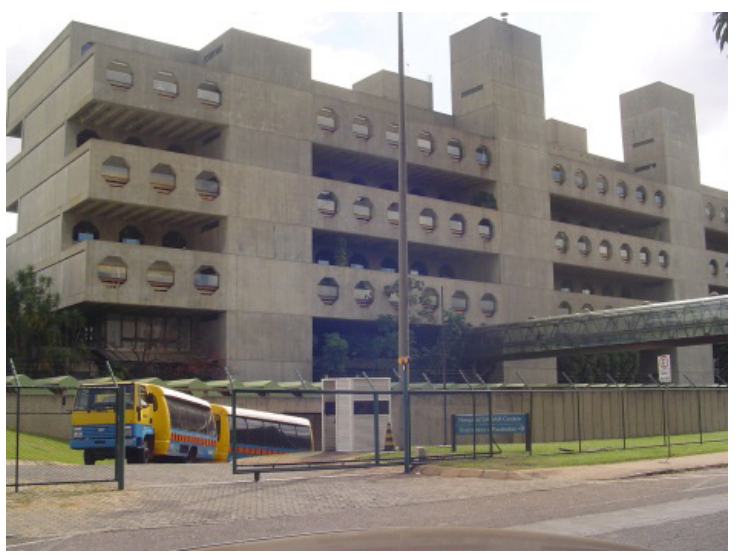

The manufacturing process adopted for the Sarah Hospitals and other buildings produced in the CTRS basically uses steel frame and precast ferrocement. The entire construction process is possible due to the use of steel, considering that the use of concrete makes constructions more expensive since there are a large number of different parts that require more expensive metal molds. Furthermore, steel frame and precast ferrocement offer advantages regarding brightness, economy and transportation of prefabricated components, allowing more freedom in the designing process (GUIMARÃES, 2010).

Mr. Lima established some criteria for the design of all Sarah Network buildings, i.e. the standardization of building elements, green spaces, natural lighting and ventilation, among others that help in the process of healing of patients. The use of natural ventilation as a strategy for the achievement of thermal comfort is essential to prevent the overspending of electricity in the use of air-conditioning, since Brazil is a tropical country and most of the Sarah Network hospitals are located in places of warm and humid weather (Figures 3 and 4).

Besides Sarah Network hospitals, other public buildings were produced in the CTRS. The constructive principle was the same: industrialized buildings of steel frame and precast ferrocement. However, this article will only emphasize the design process of Sarah Network hospitals.
Figures 1 and 2. Sarah Hospitals of Brasília and Salvador. Source: Marieli Azoia Lukiantchuki. 

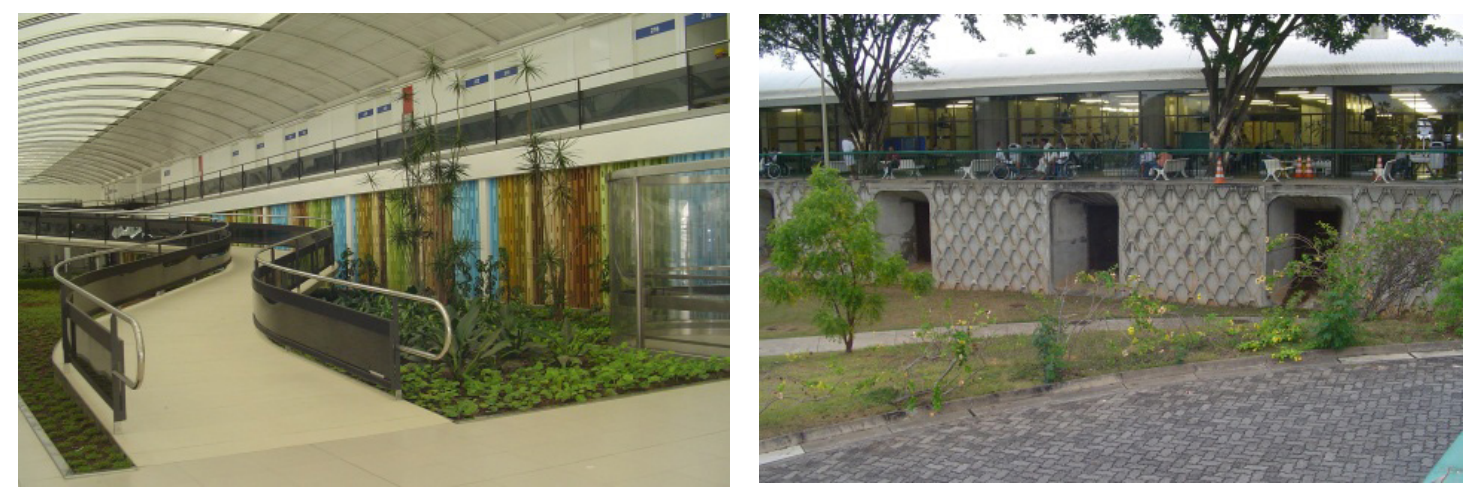

Figures 3 and 4. Natural lighting in Rio de Janeiro Hospital and natural ventilation in Salvador Hospital, respectively.

Fonte: Marieli Azoia Lukiantchuki.
Until the year 2000, the CTRS produced buildings for the Sarah Network and others for the Federal Government of Brazil not related to the network. Since 2000, the Federal Government has restricted the production of CTRS to the Sarah Network buildings. Considering the Sarah Network has no plans of building other hospitals, now the center is only working in the maintenance of the existing hospitals and in the production of hospital equipment. Only three of the five existing workshops are actively working: 1) heavy and light metallurgy, now concentrated in the same space; 2) woodwork; and 3) plastics. In 2012, the ferrocement workshop was practically stopped. At the time, the staff of almost 800 employees was reduced to 230, of which $40 \%$ are in the metal workshop, 30\% in woodworking, plastic, precast and maintenance, and $30 \%$ in administration and support.

\section{THEORY}

According to Van Nederveen et al. (2010), the current methods of work cannot support the dynamic natures of design and construction processes properly. Integrated design applies building design from a more holistic approach (ZIMMERMAN, 2006). However, the term "integrated design" has been used without a clear definition by the industry (REKOLA; KOJIMA; MÄKELÄINEN, 2010). For some authors, the concept of Integrated Design and Delivery Solutions (IDDS) considers the integration of all systems in the designing process, throughout the entire lifecycle of constructionconception, design, construction, use, maintenance, and recycling (OLIVEIRA; MELHADO, 2011; OWEN, 2009). To enhance the value delivered across the different projects during the design process, and also to maximize process and structural efficiencies, IDDS applies improved skills, knowledge management, integrated data and collaborative work processes (OWEN, 2009).

Zimmerman (2006) states the number of practitioners of Integrated Design Process (IDP) has grown, also considering that due to their practices and particular experiences, each one has a valid, but different way to conduct it. However, some features seem to appear in all definitions, such as in: interaction, allowing for previous decisions to be informed or refined through new information; collaboration, to allow architects the possibility of leading collaborations of wider teams - which includes other active roles since the beginning of the process - instead of being only the form-giver; holistic or systemic thinking, aiming the quality of the whole and not only of the parties.

A multidisciplinary team composed of experts in design, building structure and facilities is required for the design of healthcare buildings, due to the complexity of this type of building (CAIXETA et al., 2013). Therefore, an effective coordination is crucial to ensure the efficiency of the process. 
Architects are responsible for the delivery of integrated design solutions through the coordination of the different agents involved in the process and their different contributions (PRINS; KRUIJNE, 2009). Moreover, they plan and manage activities and participants during each phase of the process (KAGIOGLOU et al., 2000).

In Industrialized Building Systems (IBS), integrated design approaches may enhance architectural forms (JAGANATHAN et al., 2013), once most applications of IBS generally support conventional forms, such as square and rectangular (HAMID et al., 2008; JAGANATHAN et al., 2013). In construction, industrialization means a shift in practice and thinking, so that high quality and a customized environment can be achieved by an integrated process, enhanced organization, standardization and cost and value (GIRMSCHEID; SCHEUBLIN, 2010). The use of precast systems contributes bringing parts of the production process from the construction site to the plant, therefore, architects need to consider this system since the stage of conception of the design process to achieve suitable final results (OLIVEIRA; MELHADO, 2011; OLIVEIRA, SOUZA; SABBATINI, 2002; TAM et al., 2007).

\section{RESEARCH METHOD}

The approach adopted was the case study considering it provides grounds for the analysis of the design process developed by Mr. Lima and his team at the CTRS during the year of 2009 and of 2012. This method enables the organization and the analysis of the processes and procedures adopted at the CTRS, which configures an important and unique experience of construction industrialization in Brazil. As proposed by Yin (1994), multiple sources of evidence were used to gather data, such as direct observations, document analyses, open-ended interviews and focused interviews (Table 2). A wide and detailed study of the product development process that covers the planning, the design and the production of the plant was conducted.

For direct observations, four guided visits were carried out at the CTRS, one of them with Mr. Lima, who explained the design of the hospital and the processes of production. Subsequently, visits were made in 5 of the 10 Sarah Network Hospitals: (1) Hospital Sarah Brasília; (2) North Lake Sarah (Brasília); (3) Hospital Sarah Salvador; (4) Child Rehabilitation Center (Rio de Janeiro) and (5) Hospital Sarah Rio de Janeiro. Through the visits, the author aimed to achieve a deep understanding of the design and of the constructive and functional aspects of the buildings. In the case of Sarah Rio de Janeiro, the visits occurred in 3 stages: by the end of 2008, when the building was under construction; in 2009, when the construction was being completed, and by the beginning of 2010, with the building in operation. The analyses of documents were enabled through a survey of data of the design collection of the CTRS, with access to final designs, construction details, among other documents. Books and articles about Lelé and his work were also analyzed (Table 1 ).

As Mr. Lima's team at the CTRS was multidisciplinary, interviews with several members were conducted to enable a holistic view of the design process, which were open-ended and complemented by the focused interviews. All of them were recorded and transcribed for the creation of an information database (Table 2)

Results are discussed by following the general process of data analysis proposed by Creswell (2012) for qualitative researches, which includes the preparation and organization of the data collected to be analyzed, the division into themes and, finally, the data representation through discussion. 
Table 1. Multiple sources of evidence to collect data.

\begin{tabular}{|c|c|c|}
\hline $\begin{array}{c}\text { Sources of } \\
\text { evidence }\end{array}$ & Date/duration & Data collection \\
\hline $\begin{array}{l}\text { Direct } \\
\text { observations }\end{array}$ & $\begin{array}{l}\text { Guided tour to the CTRS: 11/18/2008 (4h } \\
\text { - during the afternoon); 11/19/2008 (8h } \\
\text { - throughout the day); and 03/18/2010 } \\
\text { (4h - during the afternoon). } \\
\text { Visitations to hospitals: 2008, 2010, } 2012\end{array}$ & $\begin{array}{l}\text { Guided tour to the CTRS with photographic survey to know } \\
\text { the production of the components of the building and to } \\
\text { understand the team work. } \\
\text { Visitations to } 5 \text { of the } 10 \text { hospitals to conduct a survey data } \\
\text { through photographs, explanatory drawings, and the analysis of } \\
\text { the constructive aspects and designs of these buildings. }\end{array}$ \\
\hline $\begin{array}{l}\text { Open-ended } \\
\text { interviews }\end{array}$ & 2009 to 2011 & $\begin{array}{l}\text { Interviews with the architect Lelé (leader of the team) and with } \\
\text { several professionals that worked with him in his designs (see } \\
\text { Table 3). }\end{array}$ \\
\hline $\begin{array}{l}\text { Focused } \\
\text { interviews with } \\
\text { key people }\end{array}$ & 2009 to 2011 & $\begin{array}{l}\text { Further clarifications on the design process and on the team } \\
\text { work. People interviewed: the architects Lelé, Adriana Filgueiras } \\
\text { Lima and Neuton Bacelar (see Table 3). }\end{array}$ \\
\hline $\begin{array}{l}\text { Analyses of } \\
\text { documents }\end{array}$ & 2008, 2010 and 2011 & $\begin{array}{l}\text { Consultation to the archive of designs of the CTRS (drawings, } \\
\text { descriptive memorials, models, and other important } \\
\text { documents). All material was photographed, resulting in } \\
\text { approximately } 1,200 \text { photos. The digital design of all hospitals } \\
\text { was provided. } \\
\text { Review of books and articles on Lelé and his work. }\end{array}$ \\
\hline
\end{tabular}

Table 2. Open-ended and Focused Interviews.

\begin{tabular}{|c|c|c|c|c|c|}
\hline Name & Profession & Description of the role & Site & $\begin{array}{l}\text { Date/ } \\
\text { Hour }\end{array}$ & Duration \\
\hline $\begin{array}{l}\text { Adriana } \\
\text { Filgueiras Lima }\end{array}$ & Architect & $\begin{array}{l}\text { Works in Lelé's team in the design } \\
\text { process of Sarah Hospitals. }\end{array}$ & $\begin{array}{l}\text { Sarah - Rio de } \\
\text { Janeiro }\end{array}$ & $\begin{array}{l}04 / 08 / 10 \\
14 h 30\end{array}$ & $3 \mathrm{~h}$ \\
\hline $\begin{array}{l}\text { Dr. Aloysio } \\
\text { Campos da Paz } \\
\text { Junior }\end{array}$ & Physician & $\begin{array}{l}\text { Chairman of the Sarah Network Board of } \\
\text { Directors and one of the creators of the } \\
\text { network. }\end{array}$ & Sarah - Brasília & $\begin{array}{l}25 / 06 / 09 \\
14 h 00\end{array}$ & $50 \mathrm{~min}$ \\
\hline Beatriz Secco & $\begin{array}{l}\text { Architect/ } \\
\text { Landscape }\end{array}$ & $\begin{array}{l}\text { Has worked with Lelé since 1979, being } \\
\text { responsible for the landscape design of }\end{array}$ & By e-mail & $\begin{array}{l}\text { 22/01/09 } \\
16 h 19\end{array}$ & ------- \\
\hline Beatriz Secco & Architect & most hospitals of the network. & & $\begin{array}{l}15 / 01 / 10 \\
12 h 41\end{array}$ & ------ \\
\hline $\begin{array}{l}\text { Denise Freire } \\
\text { Menicucci }\end{array}$ & Architect & $\begin{array}{l}\text { Works in the maintenance of buildings } \\
\text { produced at the CTRS, especially Sarah } \\
\text { Network hospitals. }\end{array}$ & $\begin{array}{l}\text { CTRS - Salvador } \\
\text { (BA) }\end{array}$ & $\begin{array}{l}\text { 18/03/10 } \\
9 h 30\end{array}$ & $50 \mathrm{~min}$ \\
\hline George Raulino & $\begin{array}{l}\text { Mechanical } \\
\text { Engineer }\end{array}$ & $\begin{array}{l}\text { Has worked with Lelé since 1980, helping } \\
\text { with thermal comfort issues. }\end{array}$ & $\begin{array}{l}\text { Estermic - } \\
\text { Brasilia }\end{array}$ & $\begin{array}{l}\text { 23/06/09 } \\
9 \text { h00 }\end{array}$ & $2 \mathrm{~h} 10 \mathrm{~min}$ \\
\hline Haroldo Pinheiro & Architect & $\begin{array}{l}\text { Participated in the design process of the } \\
\text { hospitals of Brasília (center) and Salvador. }\end{array}$ & Office in Brasília & $\begin{array}{l}25 / 06 / 09 \\
16 h 00\end{array}$ & $3 \mathrm{~h}$ \\
\hline \multirow[t]{3}{*}{$\begin{array}{l}\text { João Filgueiras } \\
\text { Lima, Lelé }\end{array}$} & \multirow[t]{3}{*}{ Architect } & \multirow{3}{*}{$\begin{array}{l}\text { Responsible for the architectural design } \\
\text { and overall coordination of Sarah } \\
\text { hospitals (design, implementation and } \\
\text { maintenance). }\end{array}$} & CTRS - Salvador & $\begin{array}{l}18 / 11 / 08 \\
14 \mathrm{~h} 30\end{array}$ & $1 \mathrm{~h} 40 \mathrm{~min}$ \\
\hline & & & $\begin{array}{l}\text { Habitat Institute } \\
\text { - Salvador }\end{array}$ & $\begin{array}{l}16 / 03 / 10 \\
14 h 30\end{array}$ & 1h30 min \\
\hline & & & Idem & $\begin{array}{l}25 / 11 / 11 \\
14 h 30\end{array}$ & $2 \mathrm{hO} 2 \mathrm{~min}$ \\
\hline \multirow[t]{2}{*}{$\begin{array}{l}\text { José Fernando } \\
\text { Minho }\end{array}$} & \multirow[t]{2}{*}{ Architect } & \multirow[t]{2}{*}{$\begin{array}{l}\text { Has worked with Lelé since } 1980 \text {, } \\
\text { following the evolution of Sarah hospitals. }\end{array}$} & $\begin{array}{l}\text { Habitat Institute } \\
\text { - Salvador }\end{array}$ & $\begin{array}{l}\text { 19/03/10 } \\
8 \text { h00 }\end{array}$ & $35 \mathrm{~min}$ \\
\hline & & & $\begin{array}{l}\text { Habitat Institute } \\
\text { - Salvador }\end{array}$ & $\begin{array}{l}24 / 11 / 11 \\
15 h 00\end{array}$ & $50 \mathrm{~min}$ \\
\hline Neuton Bacelar & Architect & $\begin{array}{l}\text { Participated in the implementation of the } \\
\text { Sarah - Salvador, being responsible for } \\
\text { the maintenance of the building. }\end{array}$ & $\begin{array}{l}\text { Sarah - } \\
\text { Salvador (BA) }\end{array}$ & $\begin{array}{l}20 / 11 / 08 \\
14 h 30\end{array}$ & $1 \mathrm{~h} 17 \mathrm{~min}$ \\
\hline \multirow{2}{*}{ Roberto Vitorino } & \multirow{2}{*}{$\begin{array}{l}\text { Civil } \\
\text { Engineer }\end{array}$} & \multirow{2}{*}{$\begin{array}{l}\text { Responsible for the conception and } \\
\text { coordination of the structural designs of } \\
\text { the hospitals of the Sarah Network. }\end{array}$} & $\begin{array}{l}\text { Office in } \\
\text { Salvador }\end{array}$ & $\begin{array}{l}\text { 19/11/08 } \\
9 \text { 9h00 }\end{array}$ & $2 \mathrm{~h} 18 \mathrm{~min}$ \\
\hline & & & Idem & $\begin{array}{l}24 / 11 / 11 \\
10 h 00\end{array}$ & 1h45 min \\
\hline
\end{tabular}




\section{RESULTS}

\section{Agents of the Integrated Design Process}

\section{Multidisciplinary team}

The design process at the CTRS involves a large multidisciplinary team with professionals from several areas:

(1) Experts in design: architects, artists, electrical, civil and mechanical engineers, professionals in visual communication and landscape architects.

(2) Experts in healthcare: physicians.

(3) Experts in production: steelworkers, woodworkers, among others.

Many of these professionals have worked together for over 30 years, which has enhanced their integration, facilitating the discussion, the design, the production and the execution of buildings. As the whole design and production occurs within the plant, integration and communication are facilitated, therefore, the various sectors of the CTRS work together in all design stages (Figure 7).

\section{User involvement}

According to the data collected, several users, as physicians, nurses and patients, were involved in the design process of the Sarah Network hospitals at the CTRS, which enables a deep knowledge on their needs and requirements. The Sarah Network hospitals are designed as simple buildings, constructed in patient's scale, so that users do not feel overwhelmed.

All programs must result from the dialogue with users, physicians and especially nurses, because I think nurses are the ones who deal with the internal problems of the hospital more frequently. Physicians take care of patients, while nurses take care of the hospital (verbal information) ${ }^{1}$.

Considering hospital buildings undergo major transformations over the years and since such buildings must be adapted to new techniques and medical requirements, the interaction with users is essential.

Lelé's concern on the needs of users has been extended to equipment. He usually designs equipment together with the staff of hospitals to understand how it should work and the main difficulties of its operation. Therefore, he believes architects should be like psychologists, discussing needs with users to absorb all the information.

There is a chair (for blood collection) I call "Celina chair", which is the name of the head of the lab. We designed it together. She has knowledge on the use and needs of patients, and the architect must capture such needs. So you must establish a very open dialogue with users (verbal information) ${ }^{2}$.

It was necessary to provide lighter and easier to carry beds to attend the need of patients for greater social life, since the existing ones did not allow displacements. Therefore, Lelé designed a gurney-bed to replace the conventional fixed beds, enabling greater mobility and avoiding the stay of patients in the wards for long periods of time. 


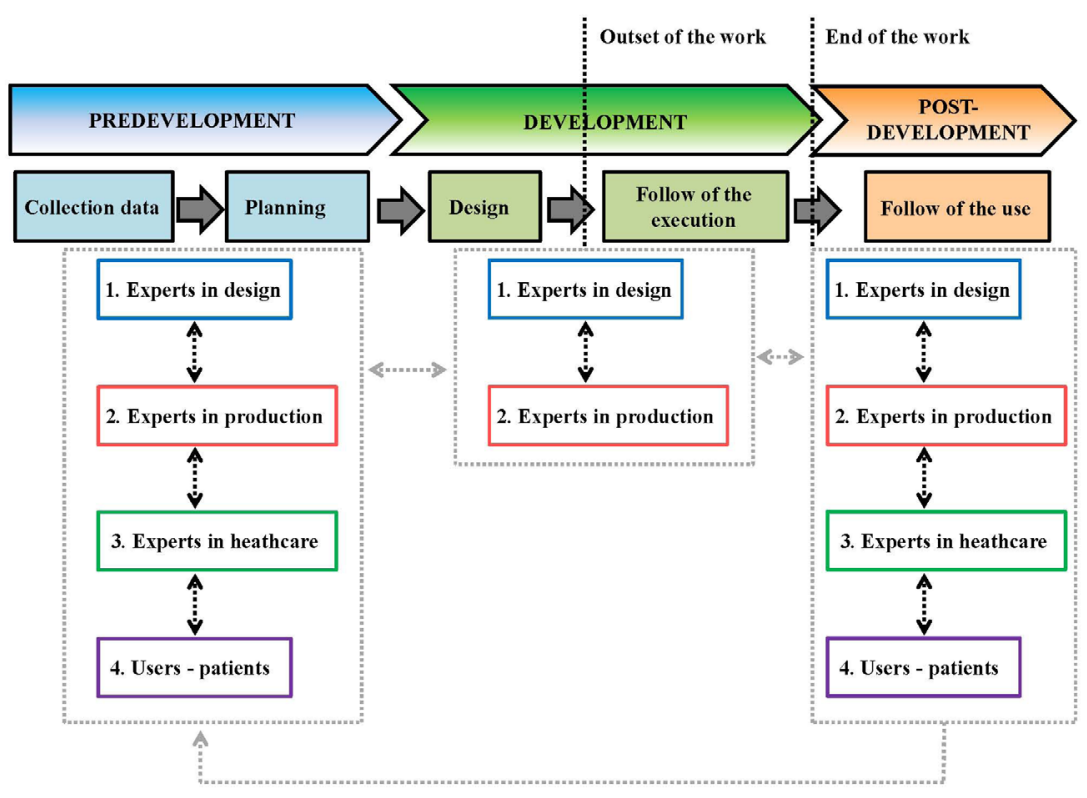

Figures 5. Organizational chart of the interation of the team members during the stages of the design process. Fonte: Chart elaborated by the authors.

\section{The architect João Figueiras Lima: the design coordinator}

The CTRS team is coordinated by Lelé, who controls all designs and production processes, i.e., the head of the plant. As the whole parts of the process including the building design, manufacture and maintenance is performed by the internal team of the CTRS, many professionals are required, which demands effective coordination. On the other hand, as they all work in the same place, the compatibility degree of different designs is facilitated.

Usually, in a conventional construction, you have a design manager who has to go from office to office making the compatibility of designs. In the case of the CTRS, this has been done daily. We were there, seeing what our colleague was doing, discussing the problem, and things were happening. If there were conflicts, they were minimal (verbal information) ${ }^{3}$.

Two important aspects led Mr. Lima to coordinate the CTRS efficiently: his academic training, with strong emphasis on technical knowledge, and his experience during the construction of Brasília, the capital of Brazil, where he headed construction sites and had several workers under his command. This experience was essential to consolidate his technical knowledge acquired in college, because that construction site was isolated by distance and must follow the deadlines. He achieved general knowledge concerning engineering, coordination and construction in the construction sites.

Due to the influence of his study trips to Eastern Europe, "Lelé" defends a broad training of architects related to construction to enable them to coordinate the whole design process. Through holistic knowledge, he can not only conduct the construction, but also be responsible for the maintenance of the Sarah Network hospitals at the CTRS.

He executes, maintains, he does everything. He is a real factory of buildings, I mean, I think he is the Bauhaus of the 21st century [...] (verbal information) $)^{4}$.

\footnotetext{
Interview conducted by the author with the architect José Fernando Minho, on March 16th, 2010, in Salvador.

Interview conducted by the author with the architect Haroldo Pinheiro, on June 25th, 2009, in Brasília.
} 


\section{Design process}

The design process developed in the CTRS encompasses all stages of planning, design, construction and maintenance, for buildings, part of the furniture and equipment. The whole team of professionals involved in each building works at the CTRS and is under the coordination of "Lelé". Such integration enables more efficiency to the design, lower costs, waste reduction and better buildings.

Hospital designs are developed at the CTRS considering the plant infrastructure, the assembling in construction sites and maintenance. Therefore, besides the architecture, structural, and other designs, the design for production and design for maintenance/of maintenance are emphasized.

Information on the production, the assembling and the use of the building can serve as feedback of the design process since the whole design and the production is held in the plant, and the CTRS also performs the building maintenance.

\section{Building design}

The architectural design is developed along with the complementary ones, providing the better performance of final results. Both design and production are developed within the plant, thus fostering the integration and communication among the professionals involved along all stages of the design process.

I believe there is no other better way of working. You have the advantage of having the structural engineer by your side, then you propose an element and can quickly check if it supports the wind force; you have the plumber checking if that is the best location for the plumbing during the design stage (verbal information) ${ }^{5}$.

In another example, "Lelé" and the mechanical engineer George Raulino, who was responsible for the design of the air-conditioning system and the thermal analysis of the building, worked together since the beginning of the design process. Along the conception stage, thermal loads of the building were analyzed by the engineer; if some strategies showed poor performance, they would be modified. According to the research findings, the integration since the beginning was more efficient than consultancies carried out after the development stage of the design, when necessary changes were more difficult to be made, thus compromising the building performance and raising costs.

The landscape design also followed this principle. Still in the conception of architectural design, the landscape architect Beatriz Secco spoke with "Lelé" about the design and started working afterwards. When the garden was already being implanted in the construction site, they re-discussed the design, making some necessary changes to better integrate the gardens with the building.

\section{Design for production}

The design for production describes how the building should be constructed in the construction site. This was crucial in the hospitals of the Sarah Network because the CTRS, where building components are produced, is located in Salvador and the buildings were constructed in several capitals of Brazil.

Mr. Lima and his team had developed the design of all the prefabricated parts. Purposeful clearances were left to avoid problems during the 
assembling and to reduce waste. Furthermore, the parts were designed according to the dimensions of the truck that would be used in their transport. In this phase, there was a deep level of detail to assist the construction execution. About 10,000 details were produced for each hospital, in 1:1, including the slots of the screws. The design team of the CTRS was concerned about the quality and the accuracy of the drawings, because they believed the architectural design must provide all necessary information to guide the construction.

As the constructive system of the hospitals of the Sarah Network was industrialized, the work in the site of the construction was mainly the assembling of the industrial components produced in the plant. Therefore, schemas were developed to facilitate and speed the assembling (Figures 6 and 7).
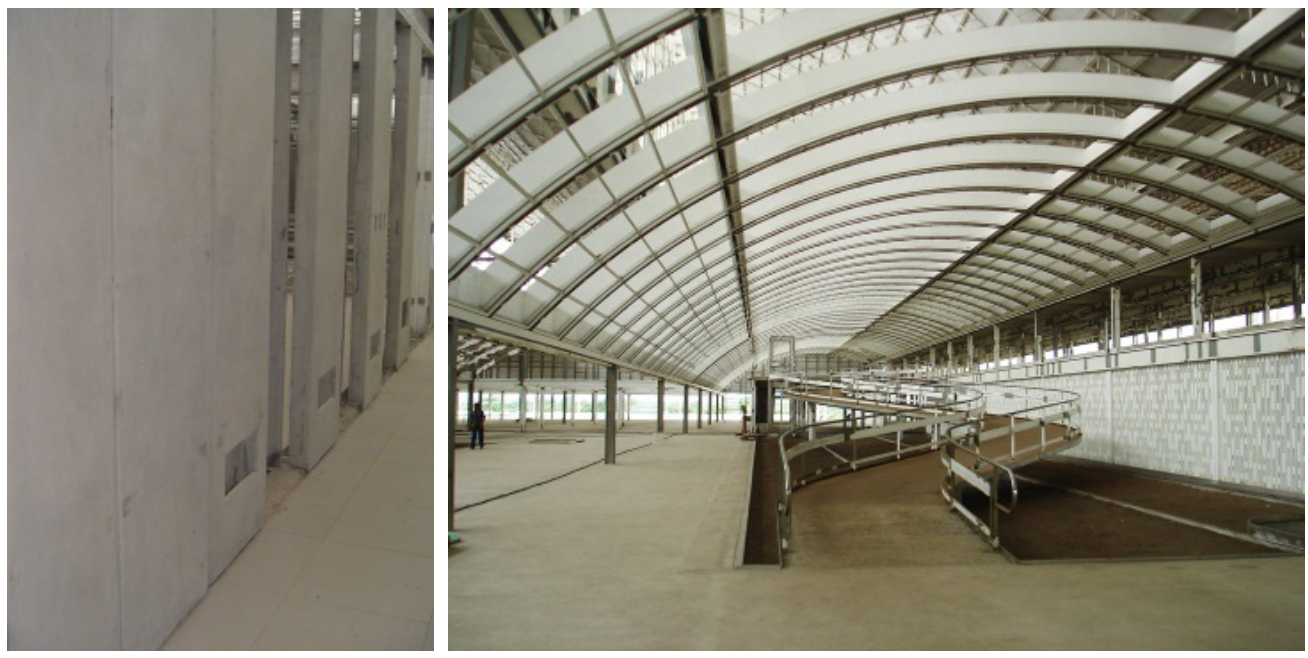

Figures 6 and 7: Wall precast ferrocement walls and metalic structure of the Sarah Hospital of Rio de Janeiro, respectively. Source: Marieli Azoia Lukiantchuki.
In the construction site, the focus of the activities was on the assembling. And we were concerned about indicating how this assembling would be held. Everything was very detailed. For example, when we did the precast schools by the FAEC, even the installation kits were already left ready in the factory. Everything was ready (verbal information) ${ }^{6}$.

According to the engineer Roberto Vitorino, the detail is the mean of communication in structural designs, being important to ensure the correct execution and to defend all professionals. Well detailed designs guarantee well performed buildings.

Most of the production, especially the more complex activities, was planned to take place within the plant, where conditions were more favorable to workers, who produced more and had greater interaction with the design team. Thereby, there was greater guarantee to produce parts as designed. Consequently, the construction site is simple and lean.

\section{Design for maintenance and design of maintenance}

The design for maintenance ${ }^{7}$ and the design of maintenance ${ }^{8}$ were developed in the CTRS. In the first case, guidelines and proposed design

Interview conducted by the author with the architect José Fernando Minho, on November 24th, 2011, in Salvador.

Design for maintenance refers to "a number of attitudes to be taken at different stages of the development process" that should be in documents and manuals to be followed during the use of the building (SANCHES; FABRICIO, 2008, 2009).

Design of maintenance refers to "definitions of maintenance programs, procedures, frequency of services, repairs and replacements” (SANCHES; FABRICIO, 2009). 
solutions aimed to facilitate the maintenance throughout the life cycle of hospitals. This is especially important in healthcare buildings to enable future adaptations to the new techniques of treatment and equipment. Equally important, the design of maintenance means that maintenance cares must be developed during the use of buildings to preserve their performance.

Hospitals are remodeled and expanded with the help of components manufactured in the CTRS with the same characteristics of the initial construction, which ensures the quality of the building throughout its life cycle.

The use of precast ferrocement walls is a sample of design for maintenance. The walls are composed of double ferrocement panels, among which all pipes and installations go by (Figure 8). Moreover, hospitals are built over underground galleries, where the maintenance of pipes and installations can be performed, not only allowing the hospital activities and but also the making of some repairs in the system. Galleries were replaced by a technical floor only in the Rio de Janeiro Hospital. However, as well as in galleries, the maintenance is carried out in the floor where installations are located (Figure 9).
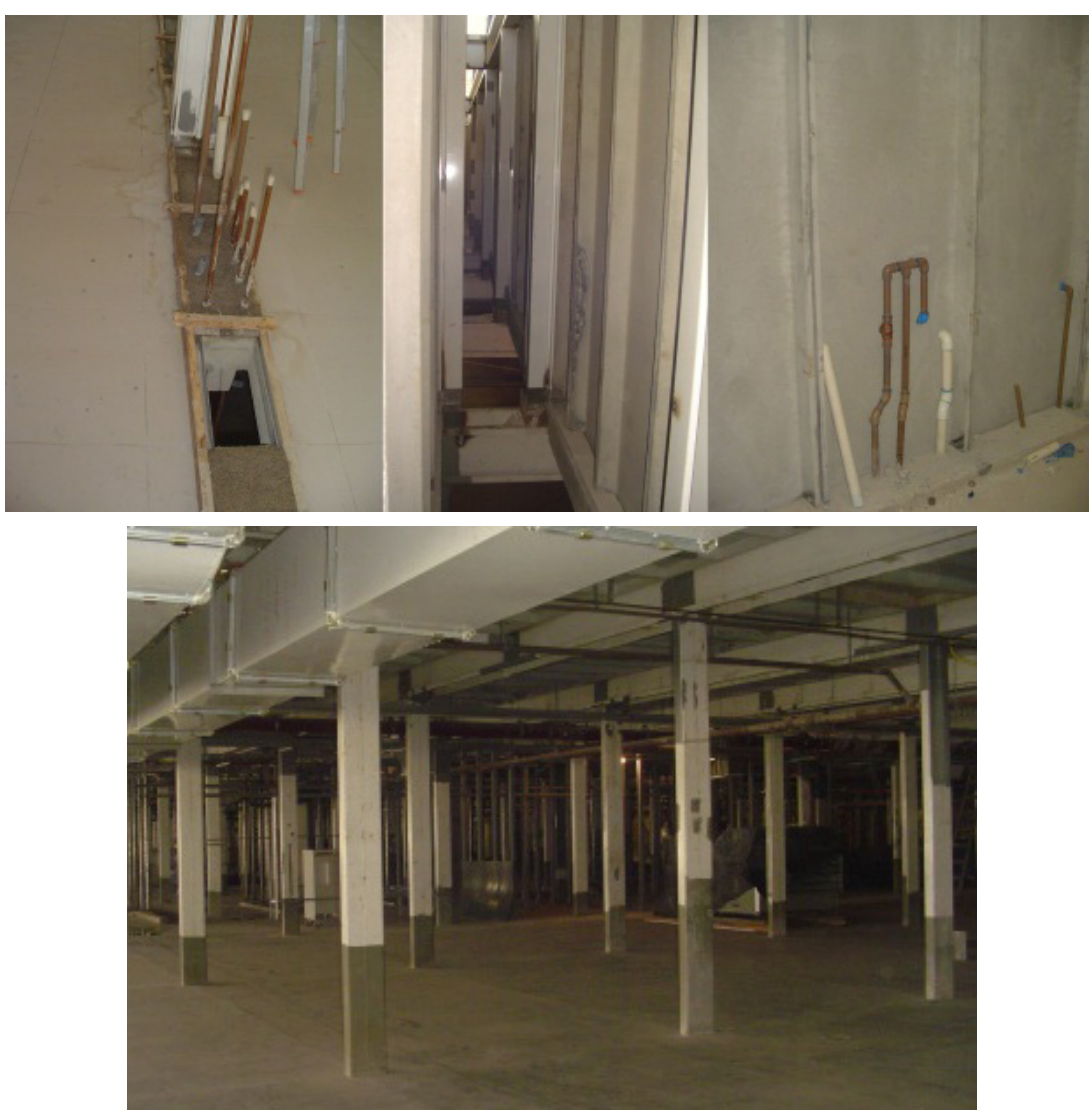

The design solutions created by Lelé are sophisticated and facilitate maintenance. For instance, there are mobile ceilings and a great roof in the sheds of the Sarah Hospital of Rio de Janeiro, always presenting a height of more than 8 meters between them, which requires rigorous maintenance for the system to work properly. For the maintenance of such devices, walkways were designed to facilitate the access (Figure 10). Furthermore, Lelé developed some equipment to facilitate the cleaning service, that by its turn, runs on rails located in the roof (Figure 11). If the maintenance and its costs are not considered in the design solutions, the building performance may be adversely affected.
Figures 8 and 9 . Precast ferrocement walls, double ferrocement panels and underground galleries of the Sarah Hospital of Rio de Janeiro. Source: Marieli Azoia Lukiantchuki. 

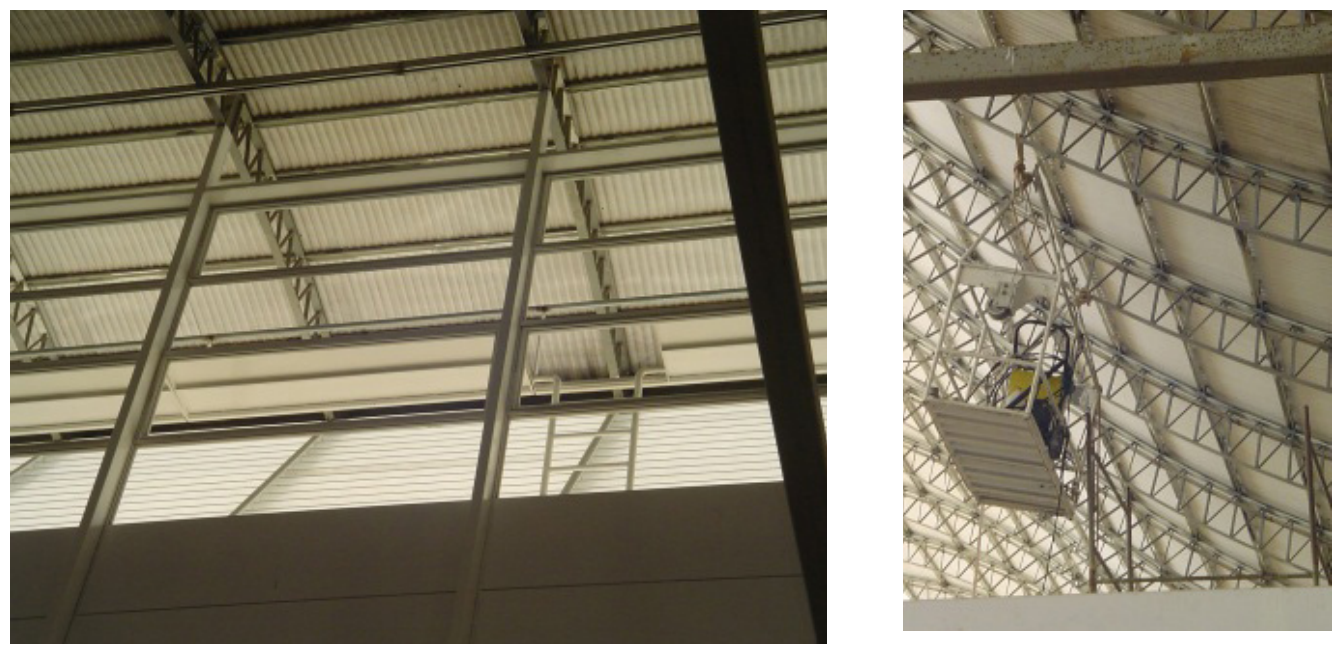

Figures 10 and 11. Walkways in great roof in sheds and equipment to facilitate the cleaning service located in the roof of the Sarah Hospital of Rio de Janeiro. Source: Marieli Azoia Lukiantchuki.

The CTRS develops the design of maintenance, and all alterations in hospital buildings during its use must be approved by the CTRS architectural sector. The maintenance is preventive, i.e., is planned in advance, reduces costs, and minimizes inactivity.

\section{FEEDBACK}

Lelé and his team worked together over 30 years, focusing on a single type of building with the same principles. It is an ongoing design process, in which each new design is seen as a continuation of the previous one. This frequent interaction between designers and buildings enables the assessment of the building operation. The practice of returning to the building after its conclusion, visiting it, and interviewing its users shows Lelé's commitment with the final results. Moreover, it means an informal feedback, through which designers acquire knowledge to apply in new designs, which provides constant evolution for the design of the hospitals of the Sarah Network.

Some design solutions adopted in the hospitals of the Sarah Network can be seen as samples of the evolution provided by the feedback. In Salvador, a frontlet with brise-soleil panels was coupled to sheds to reduce the angle of sun incidence in the hospital. However, the junction between the roof and the frontlet caused infiltration problems in rainy days due to its expansion. Therefore, in subsequent hospitals, such as in Fortaleza and Rio, the frontlet was replaced by an extension of the roof that projects itself forward (Figure 12).

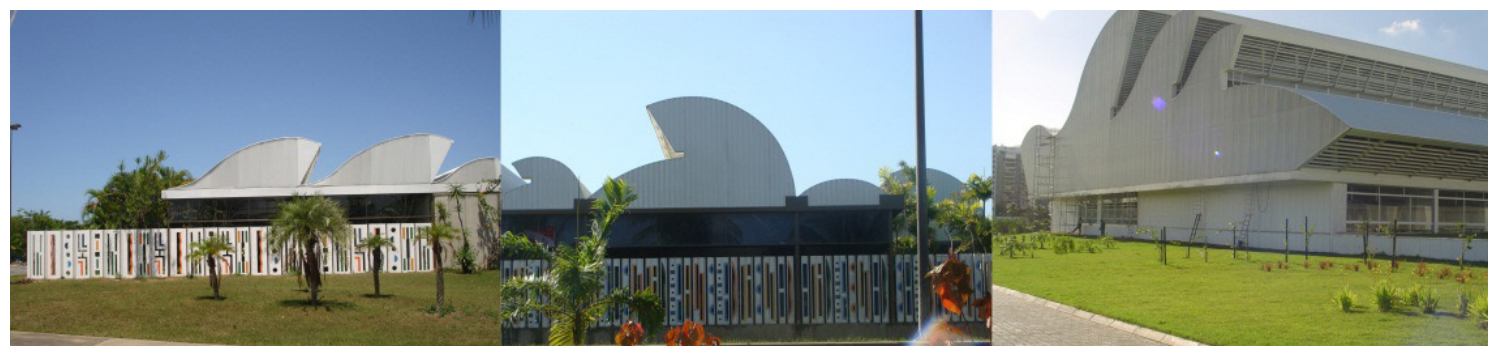

Figure 12. Sheds in Salvador, Fortaleza and Rio de Janeiro Sarah Hospital. Fonte: Marieli Azoia Lukiantchuki 
to solve comfort issues. As the system was located inside the galleries, the floor and walls were left completely wet, hindering the maintenance. Thus, in subsequent hospitals, as in the ones of Fortaleza and Rio, this system was located on the outside in water mirrors (Figure 13).

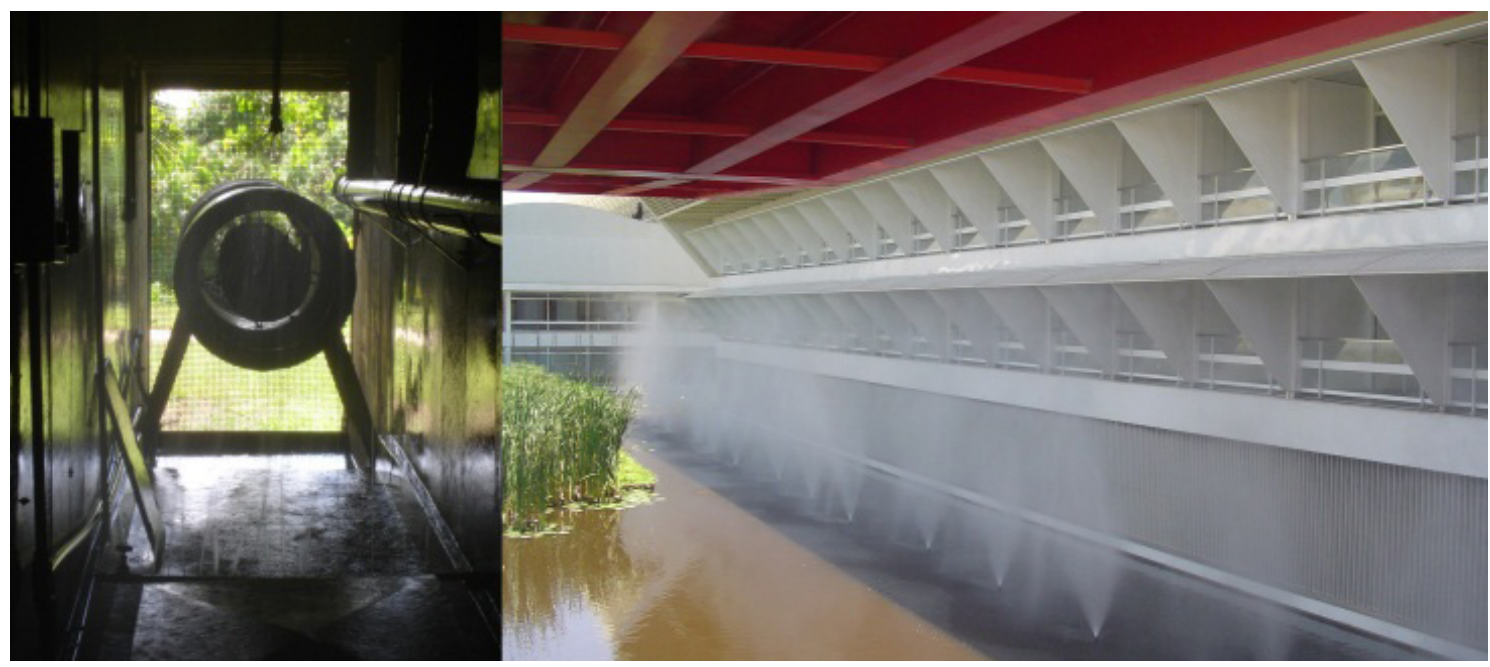

Another example is the design of the gurney-beds. The first model was built in 1974. In the subsequent years, the architect conducted tests with new materials and developed the 1997 model. Later, realizing the conditions of patients suit better to a bed with 4 divisions, instead of 3, a new version of the gurney-bed was designed in 2001. However, the biggest advance occurred in 2007, when Lelé realized the difficulty that nurses had while transferring patients from beds to wheelchairs. Thus, for convenience, it enables upward mobility. The control is motorized, which enables patients to transfer themselves alone, giving them greater independence.

\section{DISCUSSION}

In terms of industrialized construction and IDP, the CTRS stands as one of the most relevant cases in Brazil, due to the quality of buildings produced in this factory. Furthermore, the performance of its team throughout the design process is highlighted, encompassing everything from planning to maintenance, both related to the building, to the furniture and to the equipment.

The authors of this paper published other studies in the IBS at the CTRS, focusing on the production, transportation and on the assembly process in the construction site. The present paper complements this subject by showing new data in the IDP. It describes the IDP for the industrialized buildings produced in the CTRS and the influence of the factory infrastructure on design activities. The importance of IDP to improve value to client and reduce time and costs are also highlighted.

The whole design process coordinated by Lelé is developed at the CTRS, being integrated by considering several disciplines of design and different stages:

- Integration among different design disciplines: due to the complexity of healthcare buildings, a multidisciplinary design team is required. Lelé's team works together at the factory and different design disciplines are developed in an integrated way.

- Integration between architect and users: since the emergence of the CTRS, Lelé has been in close contact with healthcare professionals and patients, to help with their needs and requirements.
Figure 13. A misting system inside and outside the galleries in Salvador and Rio de Janeiro Sarah Hospital, respectively. Fonte: Marieli Azoia Lukiantchuki. 
- Integration between design and construction: the design for production is developed along the building design, both being very detailed. As design and production are held at the factory, their integration is easier.

- Integration between design and building use: designs for/of maintenance are developed during the stage of design by Lelés team.

Some of the features described by Zimmerman (2006) concerning the IDP were found at the CTRS: interaction, which enables feedback, the collaboration of different professionals and the holistic thinking, to consider the design and production of the whole hospital, including some equipment and furniture.

As the whole design process is developed at the factory and the CTRS is also responsible for maintenance, the feedback is facilitated. Understanding the opinions of users of the building during its use is important for the adaptation of designs for new buildings. The assessment of hospitals in operation performed by Lelé and his team is responsible for the major developments in Sarah Network Hospitals over these 30 years.

At the CTRS, the IDP enables the decision making of important subjects in the beginning of the design process when changes are more feasible. Therefore, costs for hospital constructions can be reduced.

Although the system construction is industrialized, the use of IDP provides innovative shapes to the building, ensuring environmental and visual quality. Research findings have shown new design challenges require greater interaction between architecture and complementary designs.

According to the results, an effective coordination is required for the management of the design team (which is very large). Lelé believes the construction process should be driven by the same coordinator of the design stage, so as to facilitate negotiations among the different parts involved in the construction and improve cooperation among the various participants. This improves the efficiency of the process as well as the quality of the product. The architect turns into a builder, in its original sense, knowing the material possibilities through his experience, having control over all the processes involved (RISSELADA, 2011). The fragmentation of knowledge has created several specialized areas, which makes the integration of these various technical sectors the main challenge of the architect.

\section{CONCLUSIONS}

This study described the IDP for industrialized hospital buildings produced at the CTRS and the influence of the factory infrastructure on design activities. A case study was used for the understanding of the design process along all stages of the building development, from planning, design, production and assembly to the building use and maintenance.

The results show that the IDP at the CTRS enables innovative shapes to the building, even when being produced by an industrialized system. Furthermore, it allows design solutions that take into account sustainable strategies of ventilation and thermal comfort, which are very important in tropical countries, such as Brazil. The IDP also facilitates the feedback and reduces costs and time along the building lifecycle. The application of IDP to the CTRS ensures environmental and visual quality and reduces time and costs, which means greater value to users.

\section{ACKNOWLEDGEMENTS}

The authors acknowledge the financial support provided by FAPESP (São Paulo Research Foundation) and CAPES (Coordination for the Improvement of Higher Education Personnel, in Brazil). They are also indebted to the participants of case study. 


\section{REFERENCES}

ANTUNES, B. Integração desde o princípio. Revista AU, v. 23, p. 58-63, 2010.

CAIXETA, M. C. B. F. et al. Value Generation Through User Involvement in Healthcare Design. In: ANNUAL CONFERENCE OF THE INTERNATIONAL GROUP FOR LEAN CONSTRUCTION, 21., Fortaleza, 2013.

CAMARGO, A. R. Industrialização da construção no Brasil. Dissertação (Mestrado) - Universidade de São Paulo, São Carlos, 1975.

CRESWELL, J. W. Qualitative inquiry and research design: choosing among five approaches (3 ed.). Thousand Oaks: Sage Publications, 2012.

GALLAHER, M. P. et al. Cost analysis of inadequate interoperability in the U.S. capital facilities industry. Gaithersburg: National Institute of Standards and Technology, 2004.

GIRMSCHEID, G.; SCHEUBLIN, F. New perspective in industrialization in construction: a state-of-the-art report. Zurich: CIB Publication 329, 2010.

GUIMARÃES, A. G. L. A obra de João Filgueiras Lima no contexto da cultura arquitetônica contemporânea. Tese (Doutorado) - Universidade de São Paulo, São Paulo, 2010.

HAMID, Z. et al. Industrialized building systems (IBS) in Malaysia: the current state and R\&D initiatives. Malaysian Construction Research Journal, v. 2, p. 1-13, 2008.

JAGANATHAN, S. et al. Integrated design approach for improving architectural forms in industrialized building systems. Frontiers of Architectural Research, v. 2, n. 4, p. 377 386, 2013.

KAGIOGLOU, M. et al. Rethinking construction: the Generic Design and Construction Process Protocol. Engineering, Construction and Architectural Management, v. 7, n. 2, p. 141-153, 2000.

LATORRACA, G. João Filgueiras Lima, Lelé. Lisboa: Blau, 1999.

LUKIANTCHUKI, M. A. A evolução das estratégias de conforto térmico e ventilação natural na obra de João Filgueiras Lima, Lelé: Hospitais Sarah Salvador e Rio de Janeiro. Dissertação (Mestrado) - Universidade de São Paulo, São Carlos, 2010.

LUKIANTCHUKI, M. A.; CAIXETA, M. C. B. F.; FABRICIO, M. M. Construction industrialization and use of prefabricated elements applied in hospital buildings production: Case study in the technology
Center of the Sarah Network of Rehabilitation Hospitals (CTRS), Brazil. In: CIB WORLD BUILDING CONGRESS, 18., Salford, United Kingdom, 2010.

LUKIANTCHUKI, M. A.; CAIXETA, M. C. B. F.; FABRICIO, M. M. Industrialização da construção no Centro de Tecnologia da Rede Sarah (CTRS). Arquitextos, ano 12, v. 134, n. 4, jul. 2011.

OLIVEIRA, L. A.; MELHADO, S. B. Conceptual model for the integrated design of building facades. Architectural Engineering and Design Management, v. 7, n. 3, p. 190-204, 2011.

OLIVEIRA, L. A.; SOUZA, U. E. L.; SABBATINI, F. H. Produtividade da mão-de-obra na execução de fachadas com painéis préfabricados arquitetônicos de concreto. In: ENTAC, 6., Foz do Iguaçu, 2002.

OWEN, R. L. CIB White Paper on IDDS Integrated Design \& Delivery Solutions. Rotterdam, The Netherlands: CIB Publication 328, 2009.

OWEN, R. L. et al. Challenges for Integrated Design and Delivery Solutions. Architectural Engineering and Design Management, v. 6, n. 4, p. 232-240, 2010.

PINHO, R. Lelé: um arquiteto universal. In: RISSELADA, M.; LATORRACA, G. (Eds.). A arquitetura de Lelé: fábrica e invenção. São Paulo: Imprensa Oficial, 2011.

PRINS, M.; KRUIJNE, K. On the management of Integrated Design Solutions. Does it work? In: INTERNATIONAL CONFERENCE ON IMPROVING CONSTRUCTION AND USE THROUGH INTEGRATED DESIGN SOLUTIONS, 1., Finland, 2009.

REKOLA, M.; KOJIMA, J.; MÄKELÄINEN, T. Towards Integrated Design and Delivery Solutions: Pinpointed challenges of process change. Architectural Engineering and Design Management, v. 6, n. 4, p. 264-278, 2010 .

RISSELADA, M. A pesquisa paciente: o CTRS como laboratório. In: M. Risselada; G. Latorraca (Eds.). A arquitetura de Lelé: fábrica e invenção. São Paulo: Imprensa Oficial, 2011.

SANCHES, I. D. A; FABRICIO, M. M. Projeto para manutenção. In: WORKSHOP BRASILEIRO - GESTÃO DO PROCESSO DE PROJETOS NA CONSTRUÇÃO DE EDIFÍCIOS, 8., 2008, São Paulo. Anais... São Paulo: USP, 2008.

SANCHES, I. D. A; FABRICIO, M. M. A importância do projeto na manutenção de HIS. In: SIBRAGEC, 6., 2009, João Pessoa. Anais... Porto Alegre: ANTAC, 2009. 
SEGAWA, H. Lelé: tecnologia com sentido social. In: RISSELEDA, M.; LATORRACA, G. (Eds.). A arquitetura de Lelé: fábrica e invenção. São Paulo: Imprensa Oficial do Estado; Museu da Casa Brasileira, p. 57-69, 2011.

SERRANO, J. S. Alojamiento y tecnologia: industrialización abierta? Madrid: Instituto Eduardo Torroja de La Construction y Del Cemento, Consejo Superior de Investigaciones Científicas, 1980.

TAM, V. W. Y. et al. Towards adoption of prefabrication in construction. Building and Environment, v. 42, n. 10, p. 3642-3654, 2007.
VAN AKEN, J. E. Valid knowledge for the professional design of large and complex design processes. Design Studies, v. 26, n. 4, p. 379-404, 2005

VAN NEDERVEEN, S.; BEHESHTI, R.; RIDDER, H. D. Supplier-driven Integrated Design. Architectural Engineering and Design Management, v. 26, n. 4, p. 241-253, 2010.

YIN, R. K. Case Study Research: design and method. Thousand Oaks: Sage Publications, 1994.

ZIMMERMAN, A. Integrated design process guide. Canada: Canadian Mortgage Housing Corporation, 2006.
Marieli Azoia Lukiantchuki mlukiantchuki@yahoo.com.br

Michele Caroline Bueno Ferrari Caixeta

michele@sc.usp.br

\section{Márcio Minto Fabricio} marcio@sc.usp.br 